Polis e Psique, Vol.1, Número Temático, 2011 Página | 166

\title{
"Jesus me ama no dark room e quando faço programa": narrativas de um reverendo e três irmãos evangélicos acerca da flexibilização do discurso religioso sobre sexualidade na ICM (Igreja da Comunidade Metropolitana)
}

"Jesús me ama hasta el dark room y cuando hago programa": narrativas de un pastor y tres hermanos evangélicos sobre la flexibilización del discurso religioso acerca de la sexualidad en la

ICM (Iglesia de la Comunidad Metropolitana)

"Jesus loves me even in the dark room": narratives of a pastor and three brothers about alternative religious discourse on sexuality in the ICM (Metropolitan Community Church)

\section{Eduardo Meinberg de Albuquerque Maranhão Filho \\ USP, São Paulo, SP, Brasil.}

\section{Resumo}

Ao pensarmos no campo religioso brasileiro, especialmente nas igrejas das variadas correntes cristãs, é comum que questões como as que envolvem as relações sexuais e afetivas e a constituição familiar através do casamento e concepção de filhos sejam linkadas à categoria da heteronormatividade. Entretanto, pululam desde a década de 1960 tentativas de acolher o público homossexual que não se coaduna com este estatuto: são as igrejas inclusivas LGBT. Dentre elas, destaco a Igreja da Comunidade Metropolitana, ou ICM, que traz como diferença em relação à maioria, o tratamento em relação à sexualidade do fiel. Apresento aqui parte das entrevistas com líderes da igreja, dentre eles três irmãos, sobre suas histórias de vida, especialmente em relação a como cada um conduz suas práticas afetivas e sexuais e assumem-nas perante os demais membros da igreja.

Palavras-chave: Igrejas Inclusivas LGBT, Sexualidade, Evangélicos

\section{Resumen}

Cuando pensamos en el campo religioso brasileño, sobre todo en iglesias de diversas corrientes cristianas, es común que las cuestiones como las relacionadas con el sexo y la formación emocional y familiar a través del matrimonio y la maternidad están vinculadas a la categoría de la 
heteronormatividad. Sin embargo, un enjambre de los intentos de la década de 1960 para acoger a los homosexuales que no cumplen con esta ley: surgen las iglesias LGBT. Entre ellas, se destaca la Iglesia Comunitaria Metropolitana, o ICM, que se diferencia en el tratamiento de la sexualidad de los fieles. En continuación presento algunas de las entrevistas con los líderes de la iglesia, entre ellos tres hermanos, acerca de sus historias de vida, especialmente en relación con la forma en que cada uno lleva sus prácticas emocionales y sexuales y las presentan ante los otros miembros de la iglesia.

Palabras clave: Iglesias Inclusivas LGBT, Sexualidad, Evangélicos

\begin{abstract}
When we think of the Brazilian religious field, especially in the Christian churches of various currents, it is common for issues such as those involving sex and emotional and family formation through marriage and procreation are linked to the category of heteronormativity. However, swarming from the 1960's attempts to accommodate homosexual population, which is inconsistent with this statute: emerge LGBT's inclusive churches. Among them, I emphasize here the Metropolitan Community Church or MCC, which brings the difference to most other treatment in relation to the sexuality of the faithful. I present here some of the interviews with three brothers on their life histories, especially in relation to how each conducts its emotional and sexual practices and take them before the other church members.
\end{abstract}

Keywords: LGBT Inclusive Churches, Sexuality, Evangelicals

Neste artigo apresento como tema o tratamento dado à sexualidade por uma agência religiosa evangélica inclusiva LGBT, a ICM (Igreja da Comunidade Metropolitana) de São Paulo, capital. ${ }^{1}$ Os fragmentos das entrevistas aqui apresentadas, feitas no segundo semestre de 2010, e em especial a entrevista feita com Josiane Ferreira de Sousa, estimularam a realização de meu projeto de doutorado em História, em andamento na Universidade de São Paulo, sob a orientação do professor José Carlos Sebe Bom Meihy, coordenador do Núcleo de Estudos em História Oral (NEHO/USP), sobre identidade, mobilidade e intolerância religiosa em relação ao 
"universo trans", representado por travestis, transexuais e transgêneros. ${ }^{2}$

Como minha dissertação de mestrado em História $^{3}$ tangenciou questões como os diferentes graus de normatização da afetividade e sexualidade de fiéis da firma religiosa neopentecostal Bola de Neve Church conhecida por receber surfistas, skatistas, modelos e famosos -, minha curiosidade situava-se em verificar se as agências religiosas que se denominam inclusivas LGBT, como a ICM, seriam, a exemplo de comunidades como a Bola de Neve, rígidas em relação às práticas sexuais - ou seriam mais flexíveis? ${ }^{4}$

\section{A ICM paulistana como agência evangélica inclusiva LGBT}

A primeira agência evangélica inclusiva a pessoas lésbicas, gays, bissexuais, travestis e transexuais (LGBT) foi, ao que se indica, a MCC (Metropolitan Community Churches), fundada pelo reverendo Troy Perry em 1968, nos Estados Unidos, associada à Fraternidade Universal das Igrejas da Comunidade Metropolitana, ou FU-ICM. Como comentei em ocasião anterior, ${ }^{5}$ amparado por entrevista com Cristiano Valério (reverendo e fundador da ICM paulistana, em 2006), Perry, filho de mãe batista e pai pentecostal, foi casado com a filha de seu pastor como forma de libertar-se de seus desejos já latentes por pessoas do mesmo sexo, e em 1962, casado, aceitou e assumiu sua orientação sexual, sendo excomungado da comunidade pentecostal que pertencia. Após cinco anos de casamento, divorciou-se, e sentindo-se traído e rejeitado por Deus, tentou o suicídio. No ano seguinte, entendeu ser possível a convivência entre os discursos sobre o cristianismo e a homossexualidade, o que o impulsionou a fundar a ICM em Los Angeles, com 12 congregados. ${ }^{6}$ Perry, casado com Philip Ray DeBliek há mais de 20 anos, escreveu obras como "O Senhor é meu pastor e Ele sabe que eu sou gay" e "Não tenho mais medo", e discutiu os direitos da população LGBT com presidentes como Jimmy Carter, em 1977, e Luis Inácio Lula da Silva, em 2003 (debatendo o Programa Nacional por um Brasil Sem Homofobia).

A ICM paulistana foi primeiramente reconhecida como Grupo de Implantação (2004) pela FU-ICM, 
tendo como líder Cristiano Valério, e oficializada como igreja em 2006, também sob sua liderança. Antes disto, houve tentativas de implantação da mesma por outros indivíduos, como Kim Ferreira, ex-pastor da Igreja Apostólica Renascer em Cristo, em 2002, e que, bem como Valério, participou da Igreja Acalanto (2002-2004), uma das primeiras agências evangélicas auto-denominadas inclusivas LGBT.

Em 2012, além da ICM, existem na cidade de São Paulo outras agências inclusivas LGBT, como a Igreja Evangélica Para Todos (ICEPT) e a Comunidade Cristã Nova Esperança (CCNE), também fundadas por exintegrantes da Acalanto em 2004, respectivamente Indira Valença e Justino Luis, a Igreja Apostólica Nova Geração em Cristo, dissidência da Para Todos, fundada em 2010 pela pastora Andréa Gomes, a Comunidade Cidade de Refúgio, inaugurada em 2011 pela missionária Lanna Holder (anteriormente líder de ministério de reversão da homossexualidade associado à Assembleia de Deus) e a pastora Rosania Rocha, com sede na Av. São João, e filiais em outras cidades (o que também ocorre com a ICM, ICEPT e CCNE), sendo a agência inclusiva LGBT que mais tem apontado crescimento, o Movimento Fonte de Justiça, fundado em 2011, em São Paulo, por Kim Ferreira (que comentou ter sido também líder da CCNE, e cuja agência religiosa encontrase, segundo o mesmo, em processo de reformulação) e a Reunião Apostólica Cristã Amanhecer, inaugurada em janeiro de 2012, por membros de inclusivas como a Para Todos, constituída por reuniões caseiras aos sábados à noite no prédio apelidado "Redondo", na Av. Ipiranga, 81 (que costuma abrigar número considerável de mulheres e travestis que vivem da prostituição), e por reuniões aos domingos, pela manhã, no Parque do Ibirapuera, também em São Paulo. Segundo seus líderes me comentaram em abril de 2012, o grupo também está em processo de reformulação - o que pode apontar para a pouca solidez de algumas destas comunidades. Todas estas agências se situam no centro de São Paulo, em locais onde há grande contingente de público LGBT, em uma área tradicionalmente chamada de Triângulo Rosa. 
Em comum às demais firmas evangélicas, boa parte delas traz uma notável normatização da sexualidade e afetividade dos crentes: direcionam-se ao público LGBT e procuram regular a sexualidade do fiel a partir de categorias como o casamento entre 'irmãos' promovido pelo sacerdote oficial - ou como queria Pierre Bourdieu, a 'voz autorizada' (ou como ainda entendo, sacralizada) -, precedido pelo namoro 'santo', ou seja, com a anuência do pastor e a abstinência de sexo pré-nupcial. Uma desta exceções está na ICM, onde a sexualidade é medida de modo mais alternativo: o crente deve, preferencialmente, fazer sexo antes do casamento, já que a vida sexual ativa, prazerosa e saudável seria condição sine qua non para o sucesso no casamento.

Neste artigo apresento parte das entrevistas com alguns de seus líderes: o reverendo Cristiano Valério narra sobre como a instituição regula a afetividade e sexualidade dos fiéis, enquanto as vozes de três irmãos consanguíneos - o diácono Dario Ferreira Sousa Neto, o líder de louvor Levi Sousa e a cantora Josiane Sousa - reverberam alguns dos modos como cada um conduz suas práticas afetivas e sexuais e assumem-nas perante os demais membros da igreja. ${ }^{7}$

Cristiano Valério narrou, dentre outras coisas, sua origem católica e evangélica, sua experiência como líder de jovens e professor de escola dominical da Igreja Batista de Cruzeiro, cidade do interior de São Paulo, onde nasceu, e como professor de Escola Bíblica na Igreja Batista de São José dos Campos, ao mesmo tempo em que fazia o Seminário Teológico e o bacharelado em Psicologia. Seu Trabalho de Conclusão de Curso abordou as CEBs (Comunidades Eclesiais de Base) no Brasil, pesquisando os pensadores da Teologia da Libertação na América Latina, o que coincidiu com seu interesse em refletir sobre a relação entre homossexualidade e cristianismo.

Fazendo a pesquisa sobre as CEBs na América Latina, descobri pela internet um encontro de jovens cristãos negros homossexuais, na Cidade do México, que ocorreu se não me engano em 1998, e eu fiquei assustado. Quando descobri quem estava promovendo fiquei mais abismado, pois era uma igreja. Era a Eclesias de la Comunidad Metropolitana, e não sabia o que era. Coloquei no Yahoo, que à época era o site de busca mais eficiente, e descobri 
que estava espalhada em toda América Latina, menos no Brasil. Não concordei, à princípio, com algumas coisas, mas achei muito interessante ter uma comunidade consolidada e com teológos e princípios, mas eu, como batista fundamentalista dentro da vertente da Batista do Sul estadunidense, que eram os xiitas do cristianismo, não concordava. $^{8}$

A partir deste contato, Cristiano envolveu-se com o CAEH-USP, Centro de Estudos Homoeróticos da USP, encontrando no sítio dos mesmos alguns textos da ICM traduzidos para o português, que como explica, foi moldando sua visão a respeito da homossexualidade e cristianismo. Ele complementa que:

Se iniciou a partir daí um grupo de implantação das ICMs no Brasil. Em 2006 recebemos a visita da reverenda bispa Darlene Gardner, que é a bispa responsável pela América Latina, definindo um grupo de implantação de igrejas em São Paulo. Soubemos que há mais de dez anos já tinha havido um grupo que tentara abrir ICM em São Paulo, mas sem sucesso dado a barreiras culturais e de comunicação. Começamos a nos reunir na sala de minha casa. Estas reuniões de implantação não eram cultos, eram reuniões de partilha, estudo bíblico e da teologia inclusiva da ICM. Passada a fase de implantação, tornamonos uma missão da igreja, com celebração da eucaristia. Depois que a missão se consolidou em grupos de ação social, de militância LGBT e ministérios, através dos relatórios enviados à Região, fomos recomendados então ao Conselho de Bispos que nos reconheceu como igreja estabelecida. ${ }^{9}$

Logo abaixo, coloco parte da transcrição de uma das entrevistas realizadas por mim com Valério, onde ele comenta sobre a perspectiva da ICM sobre a afetividade e sexualidade de seus membros.

\section{'Promíscuo é o indivíduo que faz mais sexo que o invejoso'. Fragmento de entrevista com o reverendo Cristiano Valério $^{10}$}

Gosto que me chamem de Cris, porque a empregada de casa se chama Cristina, então quando o meu companheiro Ney chama 'Cris' os dois falam 'oi!', então Cris é ótimo porque não define nada! Mas na igreja também tem gente que me chama carinhosamente de 'Rev Cris'. 
A ICM procura desconstruir algumas estratégias opressoras de nossas irmãs igrejas cristãs. Por exemplo, alguns termos são usados como ferramentas de poder para classificar, subjugar os indivíduos. Esta terminologia é continuamente desconstruída à medida que a pessoa começa a conviver com a comunidade.

Dia destes alguém me ligou e perguntou: "Reverendo, gostaria de saber se vocês aceitam um membro que é promiscuo", e eu respondi que sim, que promiscuidade é algo subjetivo, que para mim este era um termo usado muitas vezes para desqualificar $e$ diminuir alguns indivíduos. Em seguida respondi que costumo classificar o promíscuo assim: é o indivíduo que faz mais sexo que o invejoso, e inveja é pecado.

Prá gente sexo é uma benção de Deus maravilhosa, e deve ser feito sem moderação. Mas deve ser feito com todo o cuidado, respeito e responsabilidade. E esta é a diferença da ICM para a maioria das igrejas tradicionais, inclusive as demais igrejas inclusivas. As demais igrejas inclusivas reproduzem o mesmo discurso das igrejas pentecostais. A diferença delas é acolher o público LGBT, mas questões como castidade tem atenção como nas demais pentecostais. Muda-se o estereótipo mas os princípios e fundamentos são os mesmos. $E$ a relação de poder é bem presente, pois há a disciplinarização. Transou antes do casamento, 'fica de banco'. Reproduz também algo frequente nas igrejas evangélicas: não importa tanto o que vocêfez, mas se os outros souberam o que vocêfez.

O problema das igrejas não é o pecado, pois todos pecam, mas sim a hipocrisia, nos posicionar como superiores aos outros. E a preguiça e acomodamento: devemos procurar melhorar um pouquinho a cada dia. Todos pecaram e estão destituídos da glória de Deus. Nada me habilita a julgar os outros. Mas os cristãos reproduzem o discurso codificado e acham que muitas de suas normas estão na Bíblia, e não estão.

A ICM de São Paulo é uma comunidade nascente, que ainda vai completar quatro anos. Temos travestis membros da igreja mas ainda não temos um trabalho específico com travestis que se prostituem. Mas temos um modo de lidar com elas. Outro dia passei com um amigo pela Amaral Gurgel e ele comentou que achava nojento elas fazerem daquilo seu ganha-pão. Em seguida perguntei quantas travestis lavavam a roupa dele, faziam a leitura do consumo de energia ou trabalhavam em companhias de gás, escolas, postos médicos. E completei: um dia que derem emprego às travestis elas saem das ruas. Elas não tem opção e encontram na rua sua maneira de subsistência. E 
estas pessoas deveriam ser mais acolhidas e amadas que apedrejadas. Um trabalho fantástico de capacitação profissional, é feito pela Irina do CRD, que qualifica estas mulheres para o mercado de trabalho. Mas ainda assim, o maior problema é que não se dá oportunidades a elas. Eu sonho em um dia ter uma casa que acolha pessoas em situação de extrema vulnerabilidade, há muitas pessoas que estão dormindo nas ruas, e muitos idosos. Vocês já viram gays idosos? Eles ficam invisíveis. Passou dos 50, é muito difícil. Não há um asilo que acolha estes travestis com idade avançada. Antes de eu ficar idoso eu sonho que a ICM tenha um lugar de acolhimento físico onde possamos contar nossas histórias, onde tenha uma cadeira de balanço e um lugar para colocar a dentadura. Claro, um local ligado a um hospital. E eu espero que tenha um bofe bem musculoso prá empurrar a cadeira de rodas, que vai ter um cilindro de oxigênio atrás $e$ aquilo é pesado prá caramba.

Hoje temos iniciativas de membros da comunidade, no sentido de visitar, assistir e acompanhar mensalmente algumas pessoas, principalmente pessoas que convivem com HIV/Aids. Acompanhamos pessoas no Emílio Ribas e no trabalho feito pela Irina no CRD porque eu sou do Conselho Municipal de Atenção à Diversidade Sexual, isto através da CADS, que é a
Coordenadoria de Assuntos de Diversidade Sexual, eи e o Dário, que é diácono da comunidade. E quando há membros da comunidade em situação de doença, fazemos visitas. Quando precisamos de alimentos, a igreja se quotiza e ajuda.

Aqui na igreja podem observar que nos banheiros tem cartazes sobre combate à doenças venéreas e Aids, aqui na frente temos folderes e folhetos que estimulam este cuidado.

Na ICM termos como santidade, cura e libertação são trabalhados de modo intenso. Veja o exemplo do termo santo. A igreja de Corinto, que se situava nesta cidade portuária recebia constantes manifestações de sincretismo e tinha muitos conflitos entre os fiéis, e era a igreja que mais dava trabalho a Pedro e a Paulo. Quando Paulo se dirije a eles em suas epístolas, mesmo eles tendo tão problemas doutrinários e de disputas, os chama de santos. Outro exemplo, em Hebreus 11, quando há a galeria da fé com homens e mulheres considerados santos pelo seu exemplo de dedicação e probidade, há pessoas que não teriam currículo para frequentar algumas das igrejas fundamentalistas brasileiras. Um destes personagens é Noé, que em um episódio relatado em Gênesis tomou um pileque de vinho, ficou pelado com aquilo pendurado e desfilou na frente da sua família, envergonhando aos seus. E ele 
é o protótipo da nova humanidade. Davi é outro, rei enaltecido como o homem segundo o coração de Deus, mas que mandou matar Urias, esposo de BatSeba para acobertar seu adultério com esta. Assim, santidade tem muito pouco a ver com a ausência de falhas $e$ defeitos, ou de pecados. Aliás, as falhas e defeitos são parte importante de nosso crescimento, pois ao causar dor temos a oportunidade da superação. Não entendemos santidade como ausência de falhas e pecados, mesmo porque, quem seriam santos, as pedras?

Ainda há a tendência de se pensar que pecado é sexo. Que sexo não só atenta contra a santidade como em algumas igrejas castidade é sinônimo de santidade. Tudo o que você faz com a genitália é pecado. O que você fizer com os olhos, com as mãos, com a boca, se relacionam a pecados leves. Aliás com a boca não, a menos que a boca não esteja na genitália! ${ }^{11}$

Outro termo que procuramos desconstruir é o da libertação. Eu costumo dizer que libertação não é troca de algemas. Outro dia me chegou um rapaz dando um testemunho dizendo "eu bebia, eu fumava, eu transava, eu ia no baile, eu dançava, eu jogava bola”, e continuava, "agora tou na igreja, Jesus me libertou, e a tou me dedicando totalmente à obra da igreja, eu evangelizo constantemente (o que quer dizer que ele irrita todos os seus colegas, se considera melhor que os outros e sua vida é fazer proselitismo).", Isto prá mim é troca de algemas. Isto não é ser liberto.

O cristianismo tem de te tornar uma pessoa mais amável e menos julgadora, e não amarga e supervaidosa. Dentro de nossa fé libertação se associa a ser livre de fato. Assim, "se o filho vos libertar, verdadeiramente sereis livres", e sou livre para não julgar os outros, para não ter a religião como instrumento de pressão e opressão ou para legitimar minha posição. É compreender que menos é sempre mais, e que não precisamos disputar nada com ninguém. Em nossa teologia não dividimos pessoas entre pecadores $e$ não pecadores. A única divisão possível neste mundo é entre pecadores que se reconhecessem como tal e pecadores que se acham melhores que os outros, e a hipocrisia é um pecado muito grave. Quando nos vemos como pecadores, não podemos ficar julgando o próximo, o único passo que damos é amá-lo, respeitá-lo, aconselhando quando necessário, mas nunca colocando a pessoa em posição de inferioridade. ${ }^{12}$

\section{Sobre a normatização das relações pela ICM, assim sinalizou Cristiano:}

$$
\begin{aligned}
& \text { As pessoas vem com suas } \\
& \text { características pessoais, religiosas e }
\end{aligned}
$$


culturais, impressas pelas expectativas sociais. Assim, quando você é solteiro se pergunta 'e aí, quando vai namorar?', quando tá namorando 'quando vai noivar', depois 'e aí, já casou?', em seguida, 'e o primeiro filho, quando vem?', depois 'então, mas vai parar só neste?'. Aí os filhos crescem e perguntam 'e aí, seu filho já tá namorando?'. É uma eterna cobrança. Não conseguimos responder à estas expectativas. Aqui na ICM nós não temos nenhuma norma de conduta em relação a estas coisas. O máximo que temos são conselhos amorosos, 'conselhos Becel', aquela coisa 'do coração'.

Quando atendemos o casal no gabinete pastoral falamos 'queridos, parabéns! Aproveitem, esta é uma fase gostosa de se conhecer e namorar, blá, blá blá, mas usem com total responsabilidade esta liberdade que vocês tem, que Deus abençoe'; e no final a gente enche a mão dos dois de preservativos. Se for um casal hetero, também. Fazemos uma oração, damos um beijo e o casal vai embora, muito feliz.

Nós nunca fazemos intervenções que não foram solicitadas. $O$ relacionamento entre duas pessoas é sempre íntimo, é um contrato que se estabelecem entre as duas. Elas são pessoas únicas e especiais e tem a liberdade de se conhecerem e fazerem desta relação única e especial, e não precisam corresponder a expectativas de modelo social algum. As pessoas tem a liberdade de construir isto sozinho. ${ }^{13}$

\section{A ICM costuma realizar bençãos matrimoniais, como aponta Valério:}

A igreja celebra um rito, quando o casal já está junto há algum tempo e já moram juntos e tal, que é a celebração de benção de união, ou casamento. $\mathrm{Na}$ ICM aconselha-se a não celebrar a união de pessoas que não tiveram ainda uma relação sexual ou que não vivam juntas. Pode ter algum reverendo que celebre, mas eu não conheço nenhum da ICM. Eu, se algum casal chegar e disser 'ah, a gente ainda é virgem', eu vou querer saber de que planeta eles vieram ou se tem algum problema de saúde. Como estão assumindo um compromisso, como se dará a manutenção disto depois? Só celebramos o rito para pessoas que estão bastante satisfeitas na cama. Não que isto seja tudo, mas é 79\%. Eu já vi relações sobreviverem à crise financeira, doença e tudo o mais, mas é mais difícil quando não há sintonia na cama.

No rito de celebração de união não se jura que estarão juntos até que a morte os separe, pois isto depende muito de fatores que não se pode controlar. Se diz que 'desejo de todo meu coração 
amar-te e respeitar-te, na alegria e na tristeza'. Afinal, quando assinamos um contrato devemos conhecer bem o que está escrito e cumprir os votos que fazemos. Aqui o casamento é a celebração de uma união já bem consolidada. E tem de estar juntos pelo amor e não pelo contrato assinado com testemunhas. Casal que se conhece há um ano não celebra a benção de união. Tem de ter comido bons quilos de sal juntos.

A ICM já fez sim celebração de casais heterossexuais, mesmo porque há muitos casais que por serem divorciados, por exemplo, não podem se casar novamente em algumas igrejas, bem como casais que já tiveram relações sexuais antes do casamento. ${ }^{14}$

\section{Cristiano Valério comentou sobre} as maneiras como a ICM entende e trabalha a identificação sexual de seus fiéis:

Em atividades em que se costuma separar homens e mulheres, nós separamos pessoas que se identificam como homens e pessoas que se identificam como mulheres. Até porque o estereótipo não vai trazer muita informação. Quando chega à igreja uma pessoa que visivelmente parece uma mulher, mas você percebe que é homem, o que ocorre com alguns travestis, costumamos perguntar 'como você gostaria de ser chamado'. Apresento prá todo mundo como 'a fulana' ou 'o fulano de tal'.' Mas já tivemos casos de travestis que chegam e falam 'meu nome é Paulo'. Ai dizemos 'ah, bem vindo Paulo, vou te apresentar ao pessoal: queridos, este aqui é o Paulo'. Mas isto pode mudar, depois de um tempo ele pode chegar e dizer 'ah, sabe que na verdade eu me sinto mais Paula do que Paulo', ou 'eu tive uma noite maravilhosa e acordei Paula', e aí a gente atualiza o cadastro! Nome: Paula. E se a pessoa for batizada na igreja ela será batizada como Paula, apresentada e respeitada como Paula.

Quanto ao batismo nós costumamos não rebatizar a pessoa se ela já foi batizada numa igreja cristã, católica ou evangélica. Mas a gente respeita a fé da pessoa. Se a pessoa diz 'eu fui batizada na igreja evangélica Florzinha de Jesus', ou 'Cuspe de Cristo', que aliás existem, mas quiserem muito ser rebatizadas tudo bem.

A coisa do gênero a gente entende que é a maneira como a pessoa se identifica, como ela se vê. É importantíssimo a gente compreender a respeito da questão das transexuais. Porque a transexualidade é uma experiência como você acordar e ir fazer xixi, e na hora que abaixa tem um negócio pendurado lá. A pessoa pensa 'como eu posso viver com isto?' Se eu sou mulher 
como faço com esta anomalia em mim? Daí os casos de depressão, de automutilação, e é por isto que a cirurgia é uma cirurgia de adequação sexual, de adaptar o corpo à pessoa ao que ela é de fato. Imagina só o transexual masculino, um irmão que nasce com o corpo feminino, vendo crescer seios, e não conseguir conviver com aquilo, ver um corpo que ele não consegue aceitar e conviver, é uma tortura e violência muito grande. E as pessoas precisam ser muito amadas, de ter sua dor um pouco amenizada.

Eu pessoalmente entendo que o preconceito contra a comunidade LGBT se dá com a questão da condição de gênero. Por exemplo, um indivíduo heterossexual que escolhe uma profissão como a de cabeleireiro ou cozinheiro, ou outra dita como feminina, será provavelmente taxado de homossexual e vítima de preconceito. Não pelo que ele faz entre quatro paredes mas dentro de uma questão de construção de gênero, de relação de poder, de machismo. Uma mulher heterossexual que goste de jogar futebol ainda hoje pode ser vítima de preconceito. Não porque seja lésbica, mas por conta de uma questão de gênero, pelo que ela representa. A relação de poder que existe dentro dum microuniverso como o cárcere dá uma boa ideia disto: os presidiários que subjugam os mais novos ou mais fracos os estupram ou curram para "rebaixálos" à condição de mulher, os humilham ao lhes dar atividades "femininas" para fazer, como faxina, por exemplo. E como inseridos numa sociedade impregnada disto, nós somos machistas, sexistas e homofóbicos.

Nós na ICM também temos preconceito, mas procuramos lidar com eles. Não podemos deixar com que os preconceitos se tornem intolerância ou violência. A ICM não é uma igreja sem preconceitos, mas de luta contra a intolerância, a discriminação $e \quad a$ violência.

Ninguém tem sua atenção chamada por ter ido a uma festa, a uma balada, ter bebido ou conhecido alguém e ter ido prá cama com ela. Aqui na ICM não. Mas nós chamamos a atenção de alguém em um caso: se esta pessoa trata a outra mal ou passa alguma ideia preconceituosa. Todas as nossas intervenções são no sentido de receber bem todas as pessoas e combater $o$ preconceito. Nós chamamos isto de processo de libertação. À medida que a pessoa caminha ela vai se libertando destes pré-conceitos e seguindo adiante. Eu entendo bem como é a questão do preconceito porque sou gay, caipira, preto e de uma família super humilde, meu pai era metalúrgico do interiorzão de São Paulo. A rua da minha casa foi calçada depois que eu saí de lá. A hora que eu saí calçaram a rua. E até na 
igreja rola preconceito às vezes. Em relação ao preconceito com a ICM, isto é comum acontecer. Sofremos preconceito de igrejas evangélicas sim, e às vezes até de comunidades que também acolhem homossexuais, que são inclusivas pero no mucho, que reproduzem o discurso opressor das igrejas fundamentalistas: 'a gente aceita gay, desde que..., e tem restrições, como poder namorar mas não fazer sexo, ou ter de se converter para frequentar. Algo assim: 'queremos dizer querido que aqui não somos como lá (lendo-se a ICM). Nós aqui somos contra a promiscuidade'. Dizem que somos liberais, ou o 'caminho da porta larga', então a gente brinca com estas coisas.

Como identifica-se neste relato, esta agência religiosa tem uma postura alternativa em relação à maioria das firmas evangélicas, inclusive de boa parte das que identificam-se como inclusivas LGBT. Nestas, muitas vezes é desejável o casamento entre frequentadores (preferencialmente) da mesma igreja e celebrados pelo reverendo oficial após namoro presidido pela abstinência e em muitos casos, após a concordância e benção pastoral. Na ICM, encoraja-se a relação sexual antes da benção matrimonial ou casamento como tática de percepção do grau de satisfação que o casal encontrará depois. Há assim certa flexibilização em relação a sexualidade e afetividade do fiel, ao contrário do que ocorre na maioria das igrejas heteronormativas e homonormativas.

Esta flexibilização é também percebida nas narrativas de três outros líderes da igreja, os irmãos Levi de Sousa, Dário Ferreira de Sousa Neto e Josiane de Sousa, nascida Josué. A conversa com estas pessoas foi sugerida, dentre outras, pelos reverendos Cristiano Valério e Fausto Filice, que assim se constituíram como espécie de ponto zero das entrevistas. A primeira destas colaborações ocorreu com Levi de Sousa, -líder do conjunto de louvor da igreja, que me recebeu numa quinta-feira posterior à entrevista com Valério, em 29 de julho de 2010 na sala da administração da ICM.

Levi nasceu em Itaquera, bairro da zona leste paulistana e criado em Guaianazes. À época da entrevista tinha 35 anos e trabalhava como auxiliar administrativo. Assim como seus irmãos, teve sua experiência religiosa fundada na Assembleia de Deus. Transcrevo abaixo parte de sua entrevista. 
Polis e Psique, Vol.1, Número Te mát ico, 2011 Página | 179

'Deus olha prá gente que é gay sim!'. Fragmento de entrevista com Levi

\section{Sousa}

Perguntei a Levi se ele tinha a vontade de se casar, e se o faria na ICM ou em outro lugar:

eu tava com o pensamento de casar com o Natanael, mas hoje não sei bem. O que vai acontecer com o dia seguinte pertence a Deus né? Basta a cada dia o seu mal, claro, no sentido de preocupação, estas coisas. O que Jesus dizia aos discípulos era isto, que 'a andorinha não faz o seu ninho mas não falta alimento prá ela'. Então não sei se vou me casar com o Natanael. Acredito que tem coisas que depende de você $e$ Deus não interfere em questões de relacionamento. Não adianta insistir em uma relação em que você está sofrendo, pois Deus não quer o sofrimento de ninguém.

Eu pretendo me casar um dia, mas hoje não tenho muita ansiedade quanto a isto, vai ser de forma natural, será saudável e que dure bastante. Não digo prá sempre pois é muito tempo, e que seja bom pros envolvidos. Penso em casar aqui na ICM, lugar onde encontrei aquele apoio no momento que mais precisei, onde solucionei conflitos internos, me senti bem comigo mesmo, questões que eu tinha como tabus eu ia atrás do Cris e esclarecia com ele, e aqui é minha casa, minha família, meu povo. $^{15}$

Sobre ser vítima de preconceito ou discriminação por ser um homossexual evangélico, comentou que:

Em 2009, a Josi estava vestida de noiva na Parada Gay, e a gente estava entregando os fliers da igreja - nada de proselitismo, estávamos só entregando, dizendo olha 'a gente pretende ser uma comunidade', não temos o pensamento 'Jesus vai te salvar mas você ter que vir aqui', é assim: 'Aqui tem o site, é uma comunidade bacana, faz bem prá mim e eu gostaria que você conhecesse. Acredito que vai fazer bem prá você também'. Esta é a nossa forma de evangelizar. 'Se você for uma vez, a gente vai ficar muito feliz, e se voltar mais vezes, mais felizes ainda'. A Bárbara, ou o Rick, é um fruto de uma das paradas, e é uma das drags da igreja. Mas a madrinha das drags da igreja é a tia Ed, a Valdirene, que é a que causa.

Mas na Parada, quando fui entregar um folheto pra um rapaz ele disse: "vocês tão loucos! Vocês estão pecando! Deus nem olha prá gente que é gay!" Que triste isto não? Deus olha prá gente que é gay sim! 
Teve outra situação ainda: tinha um rapaz que eu achei super gatinho, sabe? Como fiquei interessado nele, entreguei um flier da igreja mais prá puxar assunto... Então comentei da igreja e me empolguei, porque a gente se empolga com o que gosta. Aí adicionei ele no orkut e tal. Fui conversando com ele, perguntei se ele tinha entrado no site e perguntei se ele tinha gostado. Aí ele tomou coragem e falou "eu não acredito que é certo ser gay, meu pai é pastor da Presbiteriana e eu estou inclusive lutando prá me curar disto”. Aí uma amiga em comum comentou que ele tava fazendo aniversário, eu fui olhar no orkut (porque mostra quem faz niver e percebi que não tinha informação nenhuma. Fui ver e ele me excluiu. Ou seja, era um homossexual cristão que acreditava que precisava ser curado e que me discriminou por eu ser gay, cristão e estar bem com minha religiosidade e sexualidade.

Imagine: a criança já é gerada com a mãe pensando que ser gay é pecado, é crime, é doença. Eu acredito que a criança já no ventre da mãe ouve $e$ sente. A criança vai recebendo esta mensagem e no seu subconsciente já está esta sementinha que vai se tornando consciente quando ela cresce, e então a homofobia aflora. Daí esta gente criminosa batendo e matando gente inocente.
Assim como o negro não pediu prá ser negro, o homossexual não pediu prá ser homossexual, e eu falo prá minha mãe: 'mãe, desde que eu me entendo por gente eu sinto isto'. ${ }^{16}$

Após comentar sobre ser discriminado por outro cristão homossexual, Levi comentou entender por ter passado por coisa semelhante, e ao perceber o incômodo causado no jovem, disse ter se sentido um estranho invadindo seu próprio espaço. Em seguida comentou sobre um de seus piores momentos de auto-rejeição:

O episódio da minha tentativa de suicídio aconteceu assim: eu tinha guardado chumbinho numa gaveta prá esconder dos meus sobrinhos. Mas eu tava numa fase que não estava aguentando mais, eu estava indo $e$ cantando na igreja, e estava tendo relações homossexuais com um homem, e eu não me aceitava. Eu me sentia a pior pessoa da face da terra, a pessoa mais indigna, mais excluída, pior que um leproso ou um doente bem grave. Aí falei “Deus eu não aguento mais”. $O$ que eu fiz? Tirei tudo da gaveta, procurando o veneno, e eu não achei ele.

Nesta mesma semana meu cunhado pediu o chumbinho pois tinha visto um 
rato em um lugar, e eu falei prá ele que já tinha devolvido a ele, pois a única explicação que eu tinha para o sumiço do negócio era que eu já tinha devolvido e não lembrava. Mas ficou aquela teima e eu fui olhar na gaveta de novo. Na hora que eu abri tava ali e disse 'nossa!’. Ou seja, Deus tirou da minha visão e do meu tato prá que eu não tivesse usado ele. Porque chumbinho não mata mas ia me danificar legal. E foi um livramento que Deus me deu de um momento de loucura meu, por causa de um preconceito interno, esta homofobia internalizada, esta rejeição tremenda. ${ }^{17}$

Como identifica-se no relato, o pior caso de homofobia para Levi é a internalizada, por causar traumas de caráter mais permanente no crente homossexual. Sobre suas práticas sexuais, Levi relatou:

Ah, eu sou romântico sim, mas nos momentos em que não aparece a pessoa certa, fazer o que? Vou me virando com uma erradinha mesmo... às vezes frequento cinemas no centro ou dark rooms nas boates. Aquelas salinhas escuras onde rola uma pegação danada sabe? Claro, sempre que rola algo além eu tou previnido. E entendo que Deus me protege. É como meu irmão Dario comentou uma vez, que Jesus te ama até no dark room sabe ${ }^{18}$

Levi é filho de dona Maria de Lourdes e teve seis irmãos, todos criados na Assembleia de Deus. Destes, além dele, dois se declararam homossexuais: Dário Neto e Josiane (posteriormente se identificando como travesti, e heterossexual).

Minha terceira entrevista foi feita com Dário em seu apartamento no CRUSP, conjunto residencial da USP, onde ele faz doutorado em literatura na faculdade de Letras, no dia 17 de agosto de 2010. Nesta ocasião Dário comentou sobre sua trajetória religiosa e na militância LGBT, seu diaconato na ICM e como ele gerencia suas práticas sexuais atualmente.

\section{'Jesus te ama até no dark room'.} Fragmento de entrevista com Dário Ferreira de Sousa Neto ${ }^{19}$

Dário Souza é nascido em Ferraz
de Vasconcelos, cidade vizinha a São
Paulo, e foi criado em Guaianazes até
entrar na USP, com 20 anos, quando se
mudou para o CRUSP, onde vive até


hoje. É membro do Conselho Universitário da USP, Diretor da Associação de Pós Graduandos - APG Capital, membro fundador do Grupo PRISMA DCE-USP (grupo de discussão sobre Diversidade Sexual) e membro do Conselho Municipal de Atenção à Diversidade Sexual de São Paulo. Tem 33 anos de idade. Fez o curso de letras em 6 anos, depois entrou no mestrado em Literatura Brasileira para pesquisar sobre Machado de Assis, defendendo sua dissertação em 2008, e atualmente faz doutorado, analisando as Crônicas de Machado. Prontamente perguntei a ele sobre a expressão 'Jesus te ama até no dark room' e sobre a oração criada por ele para esta circunstâncias:

Surgiu da seguinte forma: Fiz uma palestra na ICM sobre o olhar de Deus, a partir do Salmo 139, que fala 'Senhor, tu me sondas, me conheces, sabes quando me assento e quando me levanto”, ou seja, não tem como eu me esconder dEle, pois Ele está comigo em todo o lugar. Aí tive esta sacada "Deus vai comigo até no dark room!" Eu vou transar com alguém e Deus fica do lado de fora? Não!

No dia até brinquei com o pessoal que eu fazia uma espécie de oração: 'Peço prá Deus me abençoar, tirar os cafuçus (homens feios) do meu caminho, colocar gatinhos bonitos e interessantes... peço prá Deus me proteger, que eu tenha uma ótima transa, que eu goze bastante, e que claro, não falte nunca a camisinha e que ela não estoure! Peço ainda que os anjos protejam, que eu não pegue nenhuma DST, e todas estas coisas. Às vezes a gente ainda brinca dizendo 'e que eu não passe nem receba cheque e muito menos o talão inteiro', porque tem gente que passa o talão inteiro... ${ }^{20}$

Uma das coisas que eu questionei e que eu superei tranquilamente: eu creio que Deus é onipotente, onisciente e onipresente. Se é onisciente, ele conhece tudo. Como este Deus que conhece tudo poderia se irar, ou mais, se frustrar, sendo a ira o resultado de uma frustração? Como alguém que sabe o que vai acontecer fica irado, decepcionado ou triste, sentimentos que se ligam à frustração? Como? A partir disto que eu comecei a questionar esta humanização de Deus em sua pior forma, onde Ele surge como alguém que espera algo e se decepciona, como se não conhecesse seus filhos. E foi a partir daí que eu comecei a romper com diversos valores morais que eu fui recebendo durante minha caminhada religiosa. Eu hoje não me acho mais na obrigação de me casar e constituir família. Aliás brinco com o pessoal que 
meus problemas de relacionamento começam quando a outra pessoa me diz o nome dela, pois antes disto não tenho problema nenhum. O conflito começa quando um começa sabendo o nome do outro.

E ser diácono de uma igreja e frequentar dark rooms é algo muito tranquilo prá mim e todo mundo sabe disto, do reverendo Cris a todo o pessoal. Eles sabem que eи me sinto muito bem com isto e que não rola hipocrisia. Já teve gente na igreja que me censurou pelo fato de eu ser diácono, pregar e fazer a Ceia mas ser frequentador de boates e dark rooms. E ao mesmo tempo, também já fui acompanhado por outras pessoas da igreja: na ICM de Belo Horizonte a gente saiu da igreja e foi prá boate. Eu me enfiei no dark room na cara-dura, $e$ outros membros também acabaram se enfiando. $^{21}$

\section{'Deus me ama no dark room e quando faço programa'. Fragmento de entrevista com Josiane Sousa ${ }^{22}$}

A terceira entrevista foi realizada com Josiane, a caçula de Levi e Dário. A entrevista foi feita no apartamento de Dario no CRUSP numa quinta-feira dia 04 de novembro, por volta das 16 h. Este dia foi marcado por um ato público promovido pelo grupo Prisma, liderado por Dario, contando com apoio da ICM, que teve como representantes os reverendos Cristiano e Fausto e diversos membros, dentre eles Levi e Josiane. A entrevista com Josi interpolou momentos de entusiasmo e de certa melancolia. Eis abaixo o resultado parcial da mesma.

\footnotetext{
Meu nome é Josiane, tenho 23 anos, sou uma travesti, evangélica. Travesti é uma pessoa que nasceu em um corpo masculino, mas se sente uma mulher, tem desejos de mudar seu corpo e não tem problemas com seu órgão genital masculino... tanto faz como tanto fez... não é como o transsexual, é a pessoa que nasceu no corpo masculino e sente uma mulher mas não aceita seu órgão genital... sofre, tem delírios, às vezes se mutila... fazem cirurgia... eu não me entendo como homossexual. Porque o travesti é uma mulher. Mesmo tendo o órgão genital masculino, é uma mulher. Tem atitudes de mulher, sonhos... anda como mulher, pensa como mulher, age como mulher... claro, há momentos que pensa como homem também. Quer ver um exemplo? Se eu tivesse de brigar com um cara eu pensaria como homem... não ia brigar como uma mulher, dar um tapinha na cara dele... ia enfiar um soco na cara dele! Porque querendo ou não eu estou num corpo de
} 
homem... eu tenho uma força física de um homem. E tem algumas travestis que fazem programa que metem a mão mesmo! E o homem que sai com uma travesti é hetero. Porque está saindo com uma mulher... uma mulher que tem um corpo feminino e tudo. Na minha concepção é hetero. A maior parte do público que eu atendo é ativo, porque eu tenho traços femininos e delicados, esta é a minha característica. Então chama mais a atenção de homens ativos. Mas também atendo homens passivos, que preferem que a travesti seja a ativa... mas em geral não.

Na segunda empresa que trabalhei, que era de telemarketing como a primeira, $e$ mesmo lá poucos me chamavam pelo meu nome de registro, que é Josué... a maioria já me chamava de Josi... mesmo nesta época em que eu me definia como homossexual, eu sempre era chamada de Josi. Eu ficava muito confusa, pois eu queria andar como mulher, me vestir como mulher, queria colocar peito $e$ fazer tratamentos mas tinha medo... queria tomar hormônio mas não sabia como funcionava... era totalmente inocente... hoje eu já entendo como funciona... hoje já não tenho mais medo. E no final do ano de 2007, eu conheci alguém numa balada, fui me aproximando e em dezembro recebi o convite prá ir a uma igreja num culto natalino... e mesmo com o pé atrás com igrejas, aceitei o convite e combinei com ele de ir. Na realidade eu tava indo não por causa da igreja, mas por causa dele. No dia eu tava me arrumando, e o Dario me viu me arrumando $e$ perguntou 'você vai sair?'e eu falei 'vou'. Ele falou prá onde você vai, eu falei 'vou sair com o Robson', e ele disse, 'desmarca com ele que eu quero te levar noutro lugar'. Eu falei 'não! Eu vou com ele! Já combinei com ele e não vou desmarcar não!'. Ele ficou me enchendo o saco, tanto ele como o Levi, ficaram na minha cabeça... mas eu nem quis saber... mas encheram tanto meu saco que eu liguei prá desmarcar tudo, e eles comentaram então que era prá me levar numa igreja. Aí quando liguei falei que eles tavam querendo me levar prá uma igreja e que ia ter de desmarcar. Então o Robson perguntou que igreja era, o nome e tal, e eu não sabia. Aí passei o telefone pro Dario e eles começaram a conversar. $E$ identificaram que era a mesma igreja! Ai eu disse, 'que bom, então vamos'. Então nos encontramos com ele na igreja e ficamos todos juntos lá. E creio que não exista coincidência, Deus sempre mexe nas coisas prá acontecero melhor... Quando cheguei na igreja lembrei da palavra daquela senhora que disse que Deus ia me carregar prá um lugar que me aceitasse. Quando conheci a ICM foi em final de 2007 e eu amei! Me senti bastante acolhida e fiquei. 
Sempre cantei... ajudei no que podia... eu uso a minha voz para agradecer a Deus, é através do louvor que agradeço as coisas maravilhosas que Deus tem feito por mim. Todas as coisas que ele fez provando que é fiel na minha vida... cantando eu agradeço... o louvor na minha vida é muito importante.... todas as igrejas por onde passei, ao descobrirem minha orientação sexual me impediram de cantar e me discriminaram. Não deixavam por eu ser homossexual. E quando me impediam de cantar ou ajudar na obra da igreja, eu acabava me entristecendo e me afastando.

Quando me aceitei como travesti, foi um ano depois. Na época eu era secretária da ICM e aí eu fui fazer uma viagem com o reverendo. Aí fui prá uma viagem com o Rev, mas eu não assumia ser uma travesti apesar de ir maquiada e tudo. Então o reverendo sentou comigo $e$ começou a conversar. Ele perguntou 'o que vai no seu coração? Como você se sente bem?' Eu disse 'Cris, eu me sinto muito bem quando estou como mulher, não que eu tenha vontade de me operar, isto eu não tenho... mas eu me sinto bem vestida como mulher, me passando por mulher e sendo tratada como mulher. Ser vista como mulher...'e ele disse 'então gata, você é travesti'.

Aí ele foi me explicando o que era ser travesti. Naquela época eu tava com 21 anos. Aí fui perdendo o medo de algumas coisas e acabei entendendo direito quem sou... a partir daquele dia, fui me aceitando melhor. Tanto que em 2009, no retiro da ICM, eu me batizei... pois quando eu estava na Assembléia, quem foi batizado foi o Josué. E quando fui prá ICM me entreguei a Deus sem máscara nenhuma, sem fingimentos... $e$ como Josiane.

Fiquei uns meses fora da igreja, por problemas pessoais, mas quando retornei, foi o momento mais feliz da minha vida. Eu fui até a casa do reverendo, e falei como estava me sentindo, e ele me disse 'ô gata, sabe o que acontece? Você está querendo voltar prá casa do pai, mas você está querendo voltar como jornaleira, como empregada, só que Deus é tão generoso, tão amoroso, que ele vai te pegar no colo, colocar a melhor roupa que ele tem, a melhor sandália que ele tem, o melhor anel no seu dedo, e vai fazer o melhor banquete. Porque você voltou. A filha pródiga dele voltou. Que tinha pegado parte da herança que lhe cabia, foi gastar no mundo, depois de gastar tudo ficou entre os porcos, comendo larvas prá sobreviver, lembrou que os empregados comiam melhor que o que você comia e então você voltou. E ele estica o braço mais aberto e abre o sorriso mais largo ainda... porque todo o momento ele estava esperando você voltar. Aquilo mexeu comigo, sabe? Chorei muito, e vi que realmente Deus 
me amava. Eu comecei a perceber que eu podia levar o amor de Deus a muitas pessoas que estão morrendo, que estão sendo desprezadas em igrejas e outros lugares, que estão sendo humilhadas. Que se afastam de Deus sem conhecer realmente o amor dele. Muitas pessoas estão se matando. Muitas pessoas entendem que não merecem o amor de Deus e acabam se matando. Mas Deus ama igual a todos e quer bem a todos. $O$ problema é que a maioria dos 'evangelocos' não entendem que Deus ama a todos de modo igual. E deixar o amor de Deus entrar significa aceitar. Não só os homossexuais se matam por não reconhecerem o amor de Deus e acreditar que Deus os condena, o que não é verdade, como muitas outras pessoas se sentem rejeitadas por Deus por entenderem que erraram ou pecaram. Mas não é assim. Deus ama a todos igual... o melhor momento da minha vida foi a volta, o retorno à ICM depois de uns meses que fiquei fora. Eu senti muita paz, muita segurança, muito acalentada mesmo. Me deu uma vontade muito maior de viver, de continuar a viver... de continuar a lutar pelos meus espaços e direitos... este sentimento cresceu novamente mas de uma forma bem maior. $O$ amor de Deus veio prá minha vida e eu senti de uma forma muito maior. Agora, o meu 'sim' foi um 'sim prá sempre'.
Eu tomo hormônio feminino e ele vai alterando várias coisas, uma delas é a voz. Então estou querendo voltar a fazer aulas de canto, pois estou constantemente tentando reeducar a minha voz, que se torna mais feminina a cada dia. O hormônio vai modificar muita coisa ainda, meu rosto, meu corpo vão ficando mais femininos, eu tenho vontade de colocar prótese nos seios também... mas não penso em fazer cirurgia de alteração de sexo, não... só quero ficar bem feminina...

Em relação a trabalho... eu trabalhei em empresas de telemarketing mas sofri preconceito, principalmente depois que me identifiquei como travesti. E como eu saí da casa da minha mãe, eu acabei descendo, trabalhando na avenida com programas prá eu poder me estabilizar, me organizar, deixar minha vida financeira mais tranquila... e também para ter dinheiro para fazer minhas cirurgias... Acho que vou ser mais bem aceita quando tiver mais feminina... mas acho também que nas fases em que eu não era bem aceita isto aconteceu porque na verdade eu que não me sentia bem comigo mesma, sabe? Eu não sentia bem com meu corpo. A partir do momento em que fui me sentido bem comigo mesma, tudo começou a melhorar. Isto só ocorreu quando fui me aceitando.

Eu canto na igreja, ajudo a conduzir o culto, dou alguma palavra, ajudo na 
intecessão e oração... enfim sirvo na igreja e sou uma referência... e ao mesmo tempo, faço PGs na avenida (programas)... o que a ICM prega é que Deus não nos julga pelos nossos atos, como outras igrejas fazem. Deus não vai me rejeitar por ser gorda, ou ser pobre, ou ser travesti, ou por fazer programas. Esta não é a visão da ICM. A ICM é uma igreja que inclui todos no amor de Deus. Na Assembléia, por exemplo, para fazer parte do corpo de membros, eu teria de cortar meu cabelo, andar como homem, usar roupas masculinas, namorar e casar com uma mulher e depois ter filhos, trabalhar numa empresa e sustentar casa, ser um homem de bem que cuide de meus filhos e esposa. São regras sociais mas Deus vai muito além disto. Eu trabalho atualmente como profissional de sexo, mas não sou menos amada, acolhida ou aceita por Deus. Isto vai além do que a sociedade vê ou prega, porque Deus é mais do que isto.

Eu sou profissional do sexo e estou numa igreja fazendo parte do grupo de louvor e ministro o amor de Deus... é uma coisa bem diferente sim!

Porque isto não seria aceito em outros lugares. Numa igreja você tem de seguir o padrão, ser assim e assado. Para a igreja evangélica mais tradicional, para Deus estar com você, você tem de seguir uma lista de regras. Para você não ser condenada, você tem de seguir estas normas que são determinadas por eles, e não por Deus. Não pode cortar cabelo de um jeito, o homem e a mulher devem usar roupas adequadas, especialmente nas igrejas mais pentecostais, como a Assembleia mesmo. A mulher tem de usar roupas que cubram seu corpo... não se pode ter relações antes do casamento... só depois mesmo... são regras ditadas por homens, não por Deus. Eu comparo a época que vivemos hoje com a época em que Cristo estava na Terra. Ele veio prá fazer uma revolução em relação ao verdadeiro amor de Deus. Os fariseus usavam a Lei dos 10 Mandamentos prá 'crescer' em cima das pessoas, julgando as pessoas e discriminando elas do amor de Deus. E Jesus veio mudar tudo isto. Ele deu um novo entendimento do amor de Deus através do Evangelho. Eu comparo o que eu vivo hoje com a época de Jesus. Porque os evangélicos são quase iguais aqueles fariseus. 'não pode isto não pode aquilo'. É uma ditadura de regras. E o mandamento de Jesus é prá amarmos uns aos outros como a nós mesmos. Isto que a gente prega aqui: o amor de Deus, sem distinguir ninguém. Deus ama a todos. Independente do que penso, de como ajo, das minhas atitudes.

O Rev Cris já falou comigo assim: 'como eu vou levar o amor de Deus a uma travesti se eu não sei o que é ter uma vida de travesti, ou saber o que 
uma travesti passou?'. Então tem coisas que acontecem na vida da gente que a gente não entende no momento mas vai nos ajudar lá na frente. Lá na frente entende o porque das coisas que acontecem. O reverendo diz que não vai me criticar de jeito nenhum nem vai me rejeitar, mas que claro, não gostaria que eu estivesse trabalhando com programa. Não exatamente pelo fato de eu estar vendendo meu corpo, mas pelos riscos que eu corro, especialmente em relação à violência, pois a homofobia ainda é muito forte e a violência com os homossexuais muito grande. Risco de eu ser assassinada, de alguém me pegar e me bater... sofrer qualquer tipo de violência... umas três ou quatro vezes tentaram me agredir. Aonde eu trabalho tem um drive in, e então todas as vezes eu corri prá dentro do drive in. Agora se não dá prá correr e fugir, tem de enfrentar. Aí a gente pega um pedaço de pau, alguma coisa e vai prá cima deles.

A primeira vez que eu quase sofri violência foi numa sexta-feira. Passaram de carro e quase me atropelaram, se eu não tivesse corrido prá dentro da calçada eles me atropelavam. Eles desceram a rua, abriram a porta, fecharam e deram a ré. Quando eles voltavam fui entrando no drive in. Eles entraram com o carro, quebraram uma garrafa na cabeça de uma menina... fizeram todo o auê. $\mathrm{Na}$ segunda vez eu tava sentada na porta do drive in, que tem uma mureta que dá prá sentar, e subiu a famosa 'gangue de motoqueiros'. São motoqueiros que se juntam e saem com pedaços de pau, pedaços de pedra... com ferro, com coisas assim... e vão prá cima das meninas. Eles são famosos naquela área. Já teve casos também do cliente sair comigo e achar que tá saíndo com uma mulher e só depois ver que sou uma travesti, e não querer pagar meu programa... já aconteceu... ele pediu prá eu devolver o dinheiro, e eu falei que não ia devolver... ele veio prá cima de mim e me agrediu, mas eu também agredi ele... saí e tudo e quando ele veio atrás de mim as meninas já me ajudaram. Ele estava a pé... e quando as meninas viram que ele estava vindo prá cima de mim prá me bater, as meninas vieram e ele fugiu. Lá é assim: se uma sofre todas sofrem. O homem hetero geralmente não vai ajudar. Não vai ajudar uma travesti... porcausa do preconceito mesmo. Quer ver? Teve um caso que aconteceu com uma amiga minha, que estava dentro do metrô, e entraram uns pivetes e começaram a zoar ela... e tava bem claro que ela tava sendo agredida verbalmente por ser travesti. Quando ela foi descer do vagão um cara deu uma bicuda no pé dela, um cara que não tinha nada a ver, tava só escutando... quando ela foi descer ele chutou ela. Ou seja, é o preconceito... lá na rua é assim: se a gente vê que uma 
vai sofrer violência a gente corre prá defender. Entende? Este é o motivo do reverendo não querer que eu faça programa. De eu sofrer qualquer violência. Não bem pelo fato de eu estar na rua vendendo o corpo. Lá na ICM a gente tem o seguinte ditado: Deus deu a vida prá cada um e cada um cuida da sua. Se é difícil cuidar da minha, vou cuidar só da minha, não vou cuidar da dos outros. Se é o momento de eu me sustentar desta forma, Deus sabe quais são as minhas necessidades, que prá eu poder me manter e guardar um pouco de dinheiro prá me operar é desta forma...

Eu não ou o tipo de pessoa que sai por aí pregando o amor de Deus... fazendo proselitismo... Às vezes as meninas perguntam qual a minha religião, elas acham interessante $e$ eu vou explicando... eu conto a minha experiência, eu conto a minha vida. Eu acredito que é melhor eu levar o amor de Deus prá elas através das coisas que eu vivi, que eu senti... não pegar um livro da Bíblia e ficar falando de algo que não é da realidade delas... é mais fácil eu levar o amor de Deus prá estas meninas através do que aconteceu com a minha vida... dando uma palavra de consolo e carinho eu tou levando o amor de Deus. Quando acontece de eu comentar sobre a igreja, não falo prá ela se tornar membro da igreja. 'Vamos que lá vai acontecer algo'... não, eu vou falar simplesmente que Deus te ama. A minha forma de levar o amor de Deus é esta: falar da minha experiência com Ele. Não é a minha função, escutar uma pregação ela escuta na igreja. Eu sirvo a Deus cantando e vivendo o amor de Deus. Mesmo na avenida. Quando a gente vive o amor de Deus a gente acaba levando ele prá muitas pessoas.

Mas entendo ainda além: creio que Deus está comigo onde quer que eu vá. Eu estou descendo prá avenida, fazendo meu programa e a todo o momento sei que Deus está ali comigo. Ele está ali do meu lado, está me ajudando, está me protegendo... Eu oro prá Deus me proteger antes, durante e depois dos programas. Deus está comigo a cada minuto, até durante os pegês. Deus me ama em todo o lugar... inclusive na avenida. Deus me ama. Deus está comigo em todo o lugar. Se eu for no dark room, Ele está lá comigo. Eu estou na avenida trabalhando, fazendo programa, Ele tá lá comigo. Eu tou ali com o cliente no procedimento de um programa, Ele tá ali comigo. Me protegendo, não deixando que nada de ruim aconteça, porque eu sou filha dEele. Deus me ama no dark room $e$ quando faço programa. Eu entreguei a minha vida a Ele, eu entreguei a minha alma a Ele. Então Ele está comigo e eu tenho esta certeza. Muitos falaram que Deus não está comigo, em muitos momentos. Mas eles não conseguem 
tirar isto de mim. Esta certeza que eu tenho é porque eu vivi minhas experiências com Ele. Este amor de Deus que eu tenho na minha vida é algo que veio até a mim. É um sentimento que cresceu em mim em todos os momentos. Deus quem provou que estava aо meu lado me protegendo sempre. Esta fé ninguém vai tirar, ninguém.

Em relação a relacionamentos eu sofri bastante. Hoje em dia as pessoas querem relacionamentos sem compromissos, só sexo, e o que eu gostaria mesmo era de uma relação estável, com amor, respeito, admiração, carinho, fidelidade. O meu sonho é ter um relacionamento hetero. Eu trabalhando, ele também... Acho que é o que toda pessoa quer né? $?^{23}$

\section{Considerações finais}

Através deste trabalho, que se iniciou em meados de julho de 2010 e se encontra em andamento, identifiquei algo que me deixou ainda mais sensível ao tema: a maior parte dos integrantes destas igrejas, incluíndo a ICM, é formada por evangélicos e católicos "de berço" que sofreram discriminação, rejeição e exclusão por parte de suas antigas igrejas, muitas vezes internalizando a homofobia e chegando, em alguns casos e em momentos de desespero, ao sofrimento psíquico, a automutilações e a tentativas de suicídio. As narrativas aqui postas tangenciaram o aspecto do trauma psicológico e de suas sequelas e relacionam-se intimamente com 0 surgimento e desenvolvimento das igrejas inclusivas LGBT: a rejeição e internalização da homofobia é fundante no ato de integração às mesmas, que podem ser entendidas também como espaços de atendimento da demanda de indivíduos homossexuais evangélicos e católicos sequiosos por um ambiente onde podem professar sua fé religiosa.

No caso dos três irmãos, a possibilidade de atuarem na comunidade religiosa como líderes e auxiliarem na direção de cultos a aconselhamento dos fiéis, - saliente-se que Josiane, além de travesti, faz programas sexuais na avenida - representa espécie de transgressão em relação aos paradigmas das agências religiosas cristãs sobre as pessoas que poderiam estar a serviço de Deus - ou da instituição - e ser consideradas 'santas' (Cristiano Valério comentou na entrevista descrita acima que todos seriam pecadores, divididos entre os que se 
percebem assim e os que não se percebem). Desta forma, a ICM pode ser identificada como um possível lugar de acolhimento de indivíduos LGBT, possibilitando o exercício da religiosidade cristã associada a uma prática homoafetiva e homoerótica flexibilizada e permitindo que determinadas pessoas, rechaçadas por outras firmas religiosas, possam ocupar posições de destaque perante os demais membros.

\section{Notas}

1 A expressão agências ou firmas religiosas é utilizada para sinalizar o posicionamento das instituições religiosas dentro de um mercado religioso, como professado especialmente por pesquisadores do chamado paradigma de mercado religioso (ou das economias religiosas), ou de alguns de seus comentadores, como Frigerio (2008), Guerra (2003) e Mariano (2003). Aprofundo o assunto no artigo Marketing de Guerra Santa, publicado na Horizonte, da PUC-MG (2012). A sigla LGBT refere-se a pessoas que se identificam como lésbicas, gays, bissexuais, travestis e transexuais.
2 As entrevistas foram transcritas, encaminhadas aos entrevistados para conferência e possíveis modificações, e em seguida, autorizadas pelos mesmos.

3 Minha dissertação, defendida em fevereiro de 2010 no PPGH da UDESC, foi intitulada 'A grande onda vai te pegar: mercado, mídia e espetáculo da fé na Bola de Neve Church', e identificou, dentre outros fatores, a estética corporal e o discurso sobre gênero e sexualidade como ferramentas do gerenciamento de marketing desta firma religiosa.

${ }^{4}$ Em minha dissertação uso dos termos congelado e derretido para caracterizar alguns dos discursos da Bola de Neve Church sobre questões de gênero e sexualidade: um refere-se à rigidez doutrinária, e o outro contempla relativa flexibilização em relação a alguns dos usos e costumes, como o uso de gírias, adornos, tatuagens, piercings, vestimentas, etc.

5 No artigo "Falaram que Deus ia me matar mas eu não acreditei”. Intolerância religiosa e de gênero no relato de uma travesti profissional do sexo e cantora evangélica (MARANHÃO Fo ${ }^{\circ}$ 2011).

6 Segundo o sítio da igreja, hoje a denominação possui mais de 60 mil 
membros em 22 países ao redor do mundo, com seis unidades no Brasil. Desde 2005 as ICMs são moderadas por uma mulher, a reverenda Nancy Wilson, que visitou o Brasil em 2006. História da ICM. Disponível em: www.icmsp.org/novoportal/index.php/his toria-da-icm.html. Acesso em: $12 \mathrm{de}$ novembro de 2010.

7 À época da primeira entrevista com Valério, a ICM paulistana era liderada também por Fausto Filice, ex-padre italiano que mora em São Paulo desde 2008. Em 2011 Filice saiu da ICM, abandonando sua condição de reverendo da mesma, alegando perseguição religiosa de alas católicas em relação a ter se assumido homossexual.

${ }^{8}$ Entrevista com o reverendo Cristiano Valério. Realizada por mim em 22 de julho de 2010.

${ }^{9}$ Idem

10 Fragmentos desta entrevista foram publicados nos Anais do I Seminário Internacional de História do Tempo Presente, 2011.

11 Fragmento de entrevista com o reverendo Cristiano Valério. Realizada por mim em 22 de julho de 2010. ${ }^{12}$ Idem.
${ }^{13}$ Ibidem.

${ }^{14}$ Ibidem.

15 Fragmento de entrevista com o cantor Levi de Sousa. Realizada por mim em 29 de julho de 2010.

${ }^{16}$ Idem.

${ }^{17}$ Ibidem.

${ }^{18}$ Ibidem.

19 Fragmentos desta entrevista foram publicados em artigo nos Anais do $2^{\circ}$. Theologando Internacional, 2011.

20 A expressão 'checar', como explica Dário, é relativa à defecação involuntária que pode ocorrer durante ou após a penetração anal.

${ }^{21}$ Fragmento de entrevista com o diácono Dário Ferreira de Sousa Neto. Realizada por mim em 17 de agosto de 2010.

22 Partes desta entrevista foram publicadas em artigo nos Anais do XXVI Simpósio Nacional de História - Anpuh: 50 Anos, 2011. Outros aspectos da narrativa de Josiane Ferreira de Sousa foram publicados no artigo "Falaram que Deus ia me matar mas eu não acreditei”. Intolerância religiosa e de gênero no relato de uma travesti profissional do sexo e cantora evangélica, na História Agora, edição 12, de 2011. 
${ }^{23}$ Fragmento de entrevista com a cantora Josiane Ferreira de Sousa. Realizada por mim em 04 de novembro de 2010.

\section{Referências}

Frigerio, A. (2008). O paradigma da escolha racional. Mercado regulado e pluralismo religioso. Tempo Social, revista de sociologia da USP, São Paulo, v, 20, n. 2, p. 1739.

História da ICM. Disponível em: <www.icmsp.org/novoportal/in dex.php/historia-da-icm.html>.

Acesso em: 12 de novembro de 2010.

Holder, L. (2010). O diário de uma filha pródiga. São Paulo: Atual Brasil.

Guerra, L. (2003). As influências da lógica mercadológica sobre as recentes transformações na Igreja Católica. REVER, São Paulo, n. 2, p. 1-23.

Mariano, R. (2003). Efeitos da secularização do Estado, do pluralismo e do mercado religiosos sobre as igrejas pentecostais. Civitas, Porto Alegre, v. 3, n. 1, p. 111-125.
Maranhão $\mathrm{F}^{\mathrm{o}}$., E. M. de A. (2010). A grande onda vai te pegar: mercado, mídia e espetáculo da fé na Bola de Neve Church. Dissertação de mestrado. Pós-graduação em História do Tempo Presente, Universidade do Estado de Santa Catarina (UDESC), Florianópolis, SC. . (2010). A memória como desafio para a história do tempo presente: notas sobre narrativas e traumas. História Agora - Revista de História do Tempo Presente. 9a . edição. (2012).

"Marketing de Guerra Santa": da oferta e atendimento de demandas religiosas à conquista de fiéisconsumidores. Horizonte, Belo Horizonte, v. 10, n. 25, p. 201-232. .(2010). $O$ corpo e o esporte como estratégias de marketing da Bola de Neve Church. Oralidades - Revista de História Oral da USP. .(2010).

"Olhei para Jesus e não vi nada": uma travessia da crença ao 
ateísmo. Oralidades - Revista de História Oral da USP. (2011).

"Falaram que Deus ia me matar mas eu não acreditei”. Intolerância religiosa e de gênero no relato de uma travesti profissional do sexo e cantora evangélica. História Agora - Revista de História do Tempo Presente. $12^{\mathrm{a}}$. edição. Dossiê Expressões e Questões de Gênero. São Paulo, dezembro de 2011.

$$
\text { .(2011).“ } J
$$

esus me ama até no dark room". Narrativa de um líder evangélico homossexual acerca de discursos e práticas religiosas e sexuais. (Resumos). Em 2o. Theologando Internacional - Cristianismo e Sociedade: tendências e debates (Org.), 2 o. Theologando Internacional. São Paulo, SP : Fonte Editorial. .(2011).

"Jesus me ama quando faço programa": trauma e superação na narrativa de uma travesti evangélica. (Resumos). Em XXVI Simpósio Nacional de História (Org.), Anais, XXVI Simpósio
Nacional de História - Anpuh: 50 Anos. São Paulo, SP: ANPUH. .(2011).

"Promíscuo é o indivíduo que faz mais sexo que o invejoso". Fragmento de entrevista com o reverendo Cristiano Valério. Em I Seminário Internacional de História do Tempo Presente (Org.), Anais, I Seminário Internacional de História do Tempo Presente (p. 1-14). Florianópolis, SC : UDESC.

Eduardo Meinberg de Albuquerque Maranhão Filho: Doutorando em História Social pela USP, mestre em História do Tempo Presente pela UDESC, especialista em Marketing e Comunicação Social pela Cásper Líbero. Contato: edumeinberg@gmail.com 